\title{
Home-made silver ion solid-phase extraction system for the analysis of trans fatty acids: comparison with commercial Discovery Ag-Ion SPE
}

\author{
Vilius Poškus ${ }^{1^{*}}$, \\ Vida Vičkačkaitė ${ }^{1}$, \\ Julita Dargyté ${ }^{1}$, \\ Gintautas Brimas ${ }^{2}$ \\ ${ }^{1}$ Department of Analytical \\ and Environmental Chemistry, \\ Vilnius University, \\ Naugarduko St. 24, \\ 03225 Vilnius, Lithuania \\ ${ }^{2}$ Department of General Surgery, \\ Clinic of Gastroenterology, \\ Nephrourology and Surgery, \\ Vilnius University, Šiltnamių St. 29, \\ 04130 Vilnius, Lithuania
}

\begin{abstract}
A home-made silica-based silver ion solid-phase extraction ( $\left.\mathrm{Ag}^{+}-\mathrm{SPE}\right)$ system for the fractionation and subsequent gas chromatographic analysis of trans fatty acids in human adipose tissue is developed and examined. Analytical characteristics of the home-made $\mathrm{Ag}^{+}-\mathrm{SPE}$ column were compared with those of the commercial Discovery Ag-Ion SPE column and it was demonstrated that the both columns can be applied for the fractionation of fatty acid methyl esters.
\end{abstract}

Keywords: $\mathrm{Ag}^{+}-\mathrm{SPE}$, trans fatty acids, human adipose

\section{INTRODUCTION}

There are two major sources of trans fatty acids (TFA): TFA are produced industrially through partial hydrogenation of liquid plant oils in the presence of a metal catalyst, vacuum, and high heat or can occur naturally in meat and dairy products where ruminant animals biohydrogenate unsaturated fatty acids via bacterial enzymes [1]. Recent research suggests that TFA from different sources, as well as individual isomers, elicit differential biological effects [2]. The industrially produced TFA clearly have adverse health effects in humans, are associated with cardiovascular disease, cancer, inflammation and oxidative stress, metabolic syndrome, and type 2 diabetes mellitus [3-12]. On

* Corresponding author. E-mail: poskus.vilius@gmail.com the other hand, there are data of health benefits of ruminal TFA isomers. For example, the major ruminant derived trans fatty acid, vaccenic acid, is a precursor for conjugated linoleic acid (CLA). It was determined that CLA supplementation for 24 months in healthy, overweight adults was well tolerated, induced a decrease of body fat, and might help maintain initial reductions in body fat mass and weight in the long term [13]. However, a database on the beneficial health effect of ruminal TFAs or certain TFA isomers is lacking.

Fatty acids are well absorbed by a human body and the long-term intake is reflected in the fatty acid composition of adipose tissue [14]. Thus, sensitive and easy methods for determination of TFA in human adipose tissue should help to reveal a correlation between the individual TFA content and certain diseases and are therefore important. 
Fatty acids contained in a fat sample are most commonly measured by gas chromatography after their extraction and conversion into methyl ester derivatives. However, even with the use of long and efficient capillary columns cis/trans isomers of fatty acids are hardly separated and their peaks often overlap. To separate cis/trans isomers, a pre-separation by silver-ion solid-phase extraction $\left(\mathrm{Ag}^{+}-\mathrm{SPE}\right)$ can be employed. $\mathrm{Ag}^{+}$-SPE is based on the ability of silver ions to form weak reversible charge transfer complexes with $\pi$ electrons of the double bonds of unsaturated fatty acids. The retention depends on the number of double bonds, on their configuration and on the distance between double bonds [15-18]. Cis double bonds are more easily accessible than their trans counterparts and can therefore form stronger complexes with silver ions. Thus cis isomers are retained more strongly than trans isomers.

At present, a commercial $\mathrm{Ag}^{+}$-SPE column with silver ions loaded and immobilized onto a strong cation exchange phase is available 19]. As it is stated in the literature, the commercial Discovery ${ }^{\circledR}$ Ag-Ion SPE $\mathrm{Ag}^{+}$-SPE is effective and easy to use. On the other hand, the cartridges are rather expensive.

In our previous work [20] we have successfully applied a home-made silica based $\mathrm{Ag}^{+}$-SPE column for the analysis of trans fatty acids in human adipose. In this work, further optimisation of the column preparation is presented. The results of trans fatty acids determination obtained after the fractionation of transesterified adipose tissue on the optimised home-made $\mathrm{Ag}^{+}$-SPE column and on the commercial SCX based $\mathrm{Ag}^{+}-\mathrm{SPE}$ column are evaluated and compared.

\section{EXPERIMENTAL}

\section{Reagents and solutions}

All the reagents were of analytical grade. Trans-9-elaidic methyl ester $\left(10 \mathrm{mg} \mathrm{ml}^{-1}\right)$ solution in heptane was obtained from Sigma-Aldrich (Germany). Methyl linolenate $(9 c, 12 c, 15 c)$ was purchased from Carl Roth (Germany). Mixture ME $100\left(10 \mathrm{mgml}^{-1}\right)$ solution in dichloromethane (methyl butyrate $4 \%$; methyl hexanoate $4 \%$; methyl octanoate $4 \%$; methyl decanoate $4 \%$; methyl undecanoate $2 \%$; methyl dodecanoate $4 \%$; methyl tridecanoate $2 \%$; methyl tetradecanoate $4 \%$; methyl myristoleate (9c) $2 \%$; methyl pentadecanoate $2 \%$; methyl $10 c$ pentadecenoate $2 \%$; methyl hexadecanoate $6 \%$; methyl palmitoleate (9c) $2 \%$; methyl heptadecanoate $2 \%$; methyl 10c-heptadecenoate $2 \%$; methyl octadecanoate $4 \%$; methyl oleate (9c) 4\%; methyl elaidate (9tr) $2 \%$; methyl linoleate $(9 c, 12 c) 2 \%$; methyl linoelaidate (9tr, 12tr) $2 \%$; methyl linolenate $(9 c, 12 c, 15 c) 2 \%$; methyl gamma linolenate $(6 c, 9 c, 12 c) 2 \%$; methyl eicosanoate $4 \%$; methyl 11c-eicosenoate 2\%; methyl 11c, 14c-eicosadienoate $2 \%$; methyl eicosatrienoate (11c, 14c, 17c) $2 \%$; methyl $8 c, 11 c, 14 c$-eicosatrienoate $2 \%$; methyl arachidonate (5c, 8c, 11c, 14c) 2\%; methyl eicosapentaenoate (5c, 8c, 11c, 14c, 17c) $2 \%$; methyl heneicosanoate $2 \%$; methyl docosanoate $4 \%$; methyl erucate (13c) $2 \%$; methyl docosadienoate $(13 c, 16 c) 2 \%$; methyl docosahexaenoate (4c, 7c, 10c, 13c, 16c, 19c) 2\%; methyl tricosanoate 2\%; methyl tetracosanoate $4 \%$; methyl nervonate (15c) 2\%) was obtained from Larodan (Sweden). Dichloromethane (99.8\%), methanol (99.9\%), n-hexane (98.0\%), isooctane $(99.0 \%)$, sodium sulfate $(99.0 \%)$, boron trifluoride-methanol complex (20\% solution in methanol) were purchased from Merk (Germany). Sodium hydroxide was obtained from Eurochemicals (EU). Silica gel 60 (particle size $0.063-0.2 \mathrm{~mm}$ ) was purchased from Sigma-Aldrich (Germany). Silver nitrate was obtained from Girochem (Slovenia). Silver standard $\left(10 \mu \mathrm{g} \mathrm{ml}^{-1}\right)$ solution in $5 \% \mathrm{HNO}_{3}$ was purchased from PerkinElmer (USA). The samples of human adipose tissue were obtained from the Department of General Surgery, Vilnius University Hospital.

\section{Instrumentation and conditions}

The chromatographic analysis was performed on a Shimadzu GC-2010 plus gas chromatograph equipped with an AOC-20i auto injector and a flame ionization detector. The GC system was equipped with a Restek Rtx ${ }^{\circledR}-2330$ (90\% biscyanopropyl/10\% phenylcyanopropylpolysiloxane) capillary column $(105 \mathrm{~m} \times 0.25 \mathrm{~mm}, 0.2 \mu \mathrm{m})$.

Helium was employed as a carrier gas with a linear velocity of $32.0 \mathrm{~cm} \mathrm{~s}^{-1}$. The injector temperature was held at $225^{\circ} \mathrm{C}$. Injection was performed in a split mode. The split ratio was 10:1. The oven temperature was programmed as follows: $120^{\circ} \mathrm{C}$ for $1 \mathrm{~min}$, from 120 to $250^{\circ} \mathrm{C}$ at $2^{\circ} \mathrm{C} \mathrm{min}{ }^{-1}$, and held at $250^{\circ} \mathrm{C}$ for $1 \mathrm{~min}$. The flame ionization detector temperature was held at $260^{\circ} \mathrm{C}$. Helium gas was used as make up gas at a flow rate of $30 \mathrm{ml} \mathrm{min}^{-1}$. The hydrogen flow rate was $40 \mathrm{ml} \mathrm{min}^{-1}$, the air flow rate was $400 \mathrm{ml} \mathrm{min}^{-1}$. The signal acquisition rate was $40 \mathrm{msec}$.

The silver analysis was performed on an Optima 8000 ICP-OES spectrometer and the emission signal was radially taken. The system was equipped with a $40 \mathrm{MHz}$ free-running solid-state generator and a polychromator with an echelle grating. Dual blackside-illuminated Charge-coupled Device (CCD) detector was used. An ultrasonic nebulizer was employed for sample introduction. The instrumental conditions are summarised in Table 1 .

Table 1. ICP-OES instrumental conditions employed in the present work

\begin{tabular}{cc}
\hline Emission line measured, $\mathbf{n m}$ & $\mathrm{Ag} / \mathbf{3 2 8 . 0 6 8}$ \\
\hline Number of replicates & 3 \\
\hline Power, $\mathrm{W}$ & 1300 \\
\hline & 8 (plasma) \\
\hline Air flow, I min & \\
& 0.3 (auxiliary) \\
\cline { 2 - 2 } & 0.58 (nebulizer) \\
\hline Plasma view & Radial \\
\hline Liquid flow, $\mathrm{ml} \mathrm{min}^{-1}$ & $2.5 \mathrm{ml} \mathrm{min}^{-1}$ capillary \\
\hline
\end{tabular}




\section{Derivatization}

$50 \mathrm{mg}$ of lipids was transferred into a $100 \mathrm{ml}$ flask, $5 \mathrm{ml}$ of a methanolic sodium hydroxide solution $\left(0.5 \mathrm{~mol}^{-1}\right)$ was added, and the mixture was refluxed in a water bath for $30 \mathrm{~min}$. Then $5 \mathrm{ml}$ of boron trifluoride in methanol $(20 \% \mathrm{w} / \mathrm{v})$ was added through the top of a condenser, and the mixture was refluxed for $3 \mathrm{~min}$. The flask was removed from the water bath, and $5 \mathrm{ml}$ of isooctane and $20 \mathrm{ml}$ of saturated sodium chloride were added. The flask was closed and shaken for $30 \mathrm{~s}$, and $50 \mathrm{ml}$ of distillated water was added.

After separation of two phases, the upper layer was removed and dried with sodium sulphate. The extract was filtered through glass wool and kept in a dark glass tube until the analysis.

\section{Preparation of a home-made silica based $\mathrm{Ag}^{+}-\mathrm{SPE}$ tube}

$1 \mathrm{~g}$ of silica was placed in a $6 \times 0.9 \mathrm{~cm}$ tube, between glass frits. The tube was covered with aluminum foil. $3 \mathrm{ml}$ of a $1 \%$ silver nitrate solution was passed through the column. The tube was washed with $10 \mathrm{ml}$ of methanol, $10 \mathrm{ml}$ of dichloromethane and $10 \mathrm{ml}$ of $\mathrm{n}$-hexane in turn.

Commercial Discovery Ag-Ion SPE based conditions Separation was made according to the recommended Discovery Ag-Ion SPE protocol [19]:

Before use the column was conditioned with $4 \mathrm{ml}$ acetone, then equilibrated with $4 \mathrm{ml}$ hexane, $1 \mathrm{ml}$ of the sample with FAMEs was loaded and 3 fractions were eluted: 1-6 ml hexane : acetone 96:4, 2-4 $\mathrm{ml}$ hexane : acetone 90:10,3-4 ml acetone. The fractions were evaporated under $\mathrm{N}_{2}$ sparge and reconstituted in $1 \mathrm{ml}$ hexane prior to the $\mathrm{GC}$ analysis.

\section{RESULTS AND DISCUSSION}

\section{Optimization of home-made silica based $\mathrm{Ag}^{+}$-SPE} column preparation and fractionation conditions It is well known that adipose tissue consists of low volatility fatty acids triglycerides that should be converted to more volatile compounds prior to the GC analysis. In our previous work [20] preliminary investigations of the fractionation of methylated adipose tissue fatty acids using a home-made silica based $\mathrm{Ag}^{+}$-SPE column demonstrated satisfactory results. Here further optimization of silica based $\mathrm{Ag}^{+}-\mathrm{SPE}$ column preparation and fractionation conditions are presented.

\section{The quantity of silver nitrate solution required to fully cover a home-made $\mathrm{Ag}^{+}-\mathrm{SPE}$ column}

$\pi$ electrons of unsaturated fatty acids form weak reversible charge transfer complexes with silver ions adsorbed on the silica column. Components with trans double bonds elute ahead of cis isomers. The bigger quantity of $\mathrm{Ag}^{+}$is present on the column, the stronger retention and conse- quently the better separation of geometrical isomers occurs. For this reason, a sufficient amount of $\mathrm{AgNO}_{3}$ solution should pass through the column in order to saturate it with silver ions. On the other hand, the price of the column strongly depends on the quantity of $\mathrm{AgNO}_{3}$ used for its preparation, thus the quantity of silver nitrate used should be sufficient to saturate silica but not excessive.

In order to determine the optimal quantity of $\mathrm{AgNO}_{3}$, five portions of $1 \%$ silver nitrate $(1 \mathrm{ml}$ each) were passed through the column, collected, diluted to $100 \mathrm{ml}$ and analysed using the ICP-OES technique. For comparison, $1 \mathrm{ml}$ of the initial silver nitrate solution diluted to $100 \mathrm{ml}$ was analysed. All the analyses were triple. The results presented in Table 2 demonstrate that $3 \mathrm{ml}$ of $1 \%$ silver nitrate is sufficient to saturate the silica column.

Table 2. Amounts of silver nitrate passed through the silica column. The determined initial concentration of $\mathrm{Ag}^{+}$is $65.72 \mu \mathrm{gl}^{-1}$

\begin{tabular}{ccc}
\hline AgNO ${ }_{3}$ portion & Passed $\mathbf{A g}^{+}, \mu \mathbf{g ~ l}$ & Passed $\mathbf{A g}^{+}, \%$ \\
\hline 1 & 0.15 & 2 \\
\hline 2 & 22.93 & 35 \\
\hline 3 & 37.53 & 57 \\
\hline 4 & 66.00 & 100 \\
\hline 5 & 65.25 & 99 \\
\hline
\end{tabular}

\section{Sample size optimization}

Sample size influence on cis-trans separation was investigated. As can be seen in Fig. 1, the most concentrated trans fraction was obtained using $0.1 \mathrm{mg}$ of the human adipose sample. When the amount of the sample was increased to $0.2 \mathrm{mg}$, more eluent $(6 \mathrm{ml})$ was required for the elution. With the further increase of the sample size, the retention of the trans fraction became weaker and an increased amount of oleic acid methyl ester in the trans isomers fraction was observed probably because the amount of silver ions on the column was insufficient to retain efficiently the analytes. For example, with $0.1 \mathrm{mg}$ sample load $95 \%$ of oleic acid methyl ester was removed from the trans fraction, meanwhile when the amount of sample was $0.2 \mathrm{mg}$, only $75 \%$ of it was removed [20]. Thus, the optimal sample load on the home-made $\mathrm{Ag}^{+}-\mathrm{SPE}$ column was determined to be $0.1 \mathrm{mg}$.

To test the column's separation efficiency, a derivatized human adipose sample was used. A solution containing $0.1 \mathrm{mg}$ of the sample was passed through the column prepared using $3 \mathrm{ml}$ of silver nitrate. The stepped gradient elution elaborated in [20] was applied. The collected fraction was evaporated to dryness, diluted to $1 \mathrm{ml}$ with hexane and analysed. The results showed (Fig. 2) that the full separation of C18:0 and C18:1 was achieved. Moreover, the trans fraction was eluted with a much smaller amount of the solvent $(3 \mathrm{ml})$. Geometric isomers were better separated and only a negligible amount of $\mathrm{C} 18: 1$ cis isomers in the trans fraction was determined. 


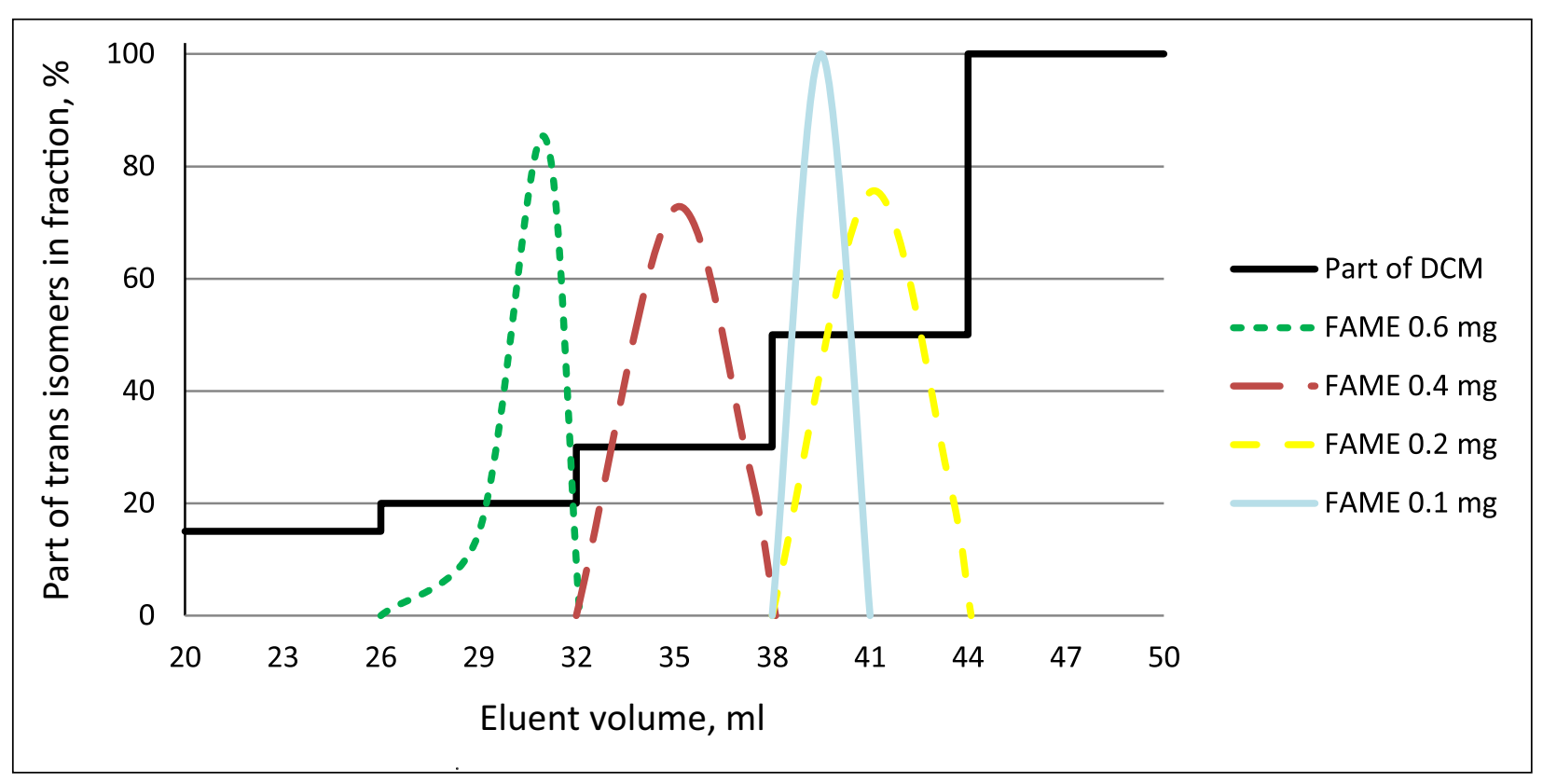

Fig. 1. Separation of trans fatty acids on the silica based $\mathrm{Ag}^{+}$-SPE column prepared using $3 \mathrm{ml}$ of $1 \% \mathrm{AgNO}_{3}$

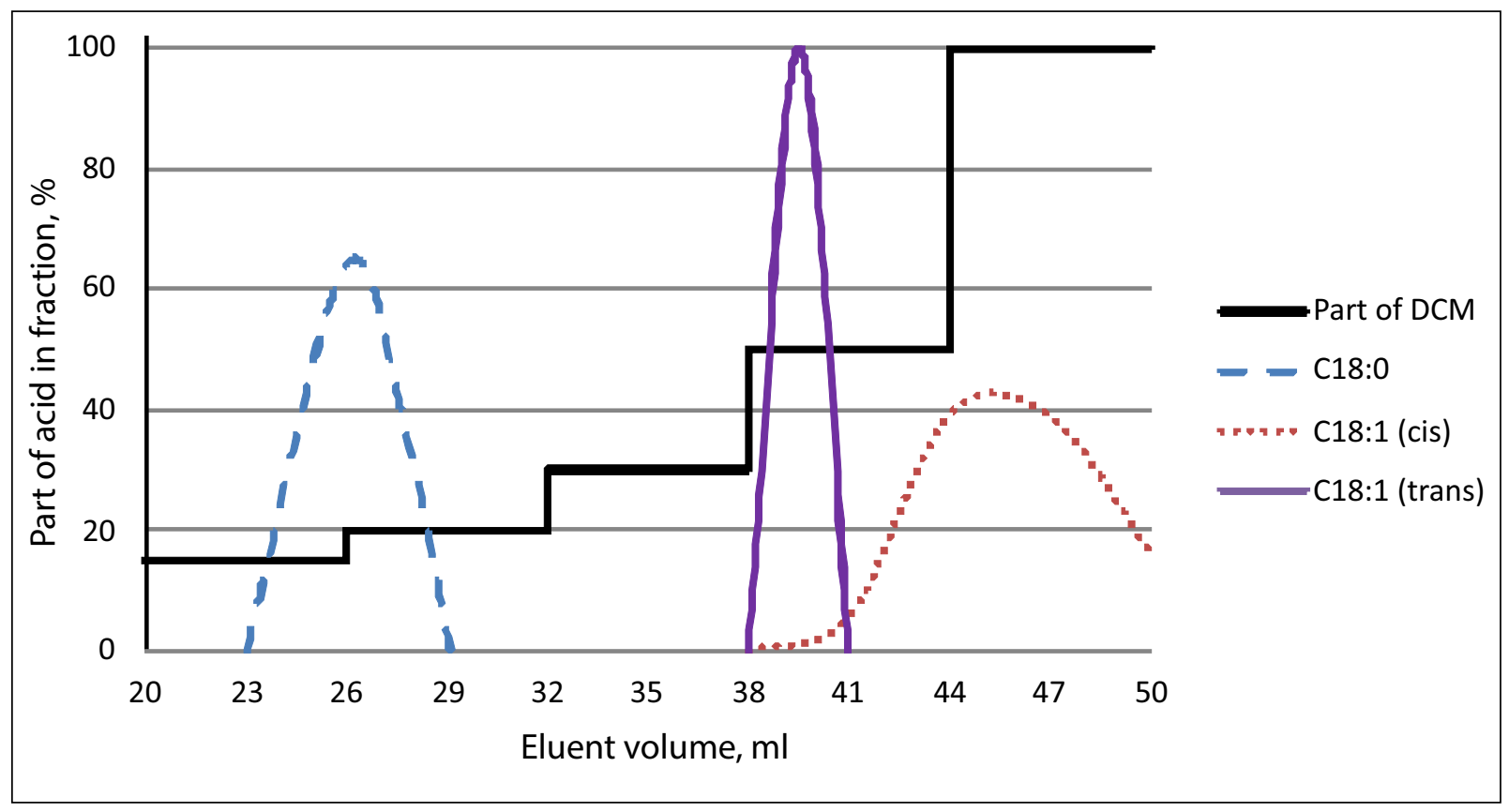

Fig. 2. Separation of fatty acids on the silica based $\mathrm{Ag}^{+}$-SPE column prepared using $3 \mathrm{ml}$ of $1 \% \mathrm{AgNO}_{3}$ and loaded with $0.1 \mathrm{mg}$ of the sample

Evaluation and comparison of a home-made silica based $\mathrm{Ag}^{+}$-SPE column and a commercial SCX based $\mathrm{Ag}^{+}$-SPE column

For a statistical evaluation of the methods involving solid phase extraction with a home-made silica based $\mathrm{Ag}^{+}$-SPE and a commercial SCX based $\mathrm{Ag}^{+}$-SPE column, the tissue of human adipose was used. The tissue was derivatized as described in the Experimental section. The worst separated fragment of the chromatogram obtained prior to the fractionation is presented in Fig. 3 a. A fragment of the chromato- gram of the trans fraction obtained after the fractionation on the home-made silica based $\mathrm{Ag}^{+}-\mathrm{SPE}$ column is presented in Fig. 3 b. For comparison, the fractionation was accomplished using the commercially available SCX based $\mathrm{Ag}^{+}$-SPE column using the protocol described in the Experimental section. A fragment of the chromatogram is presented in Fig. 3c.

Figure 3 demonstrates that before the fractionation a huge peak of C18:1 9c covers the small peaks of trans isomers that are evidenced in Fig. $3 \mathrm{~b}$ and $3 \mathrm{k}$. Contrarily, after the fractionation the major part of cis isomers is eliminated 


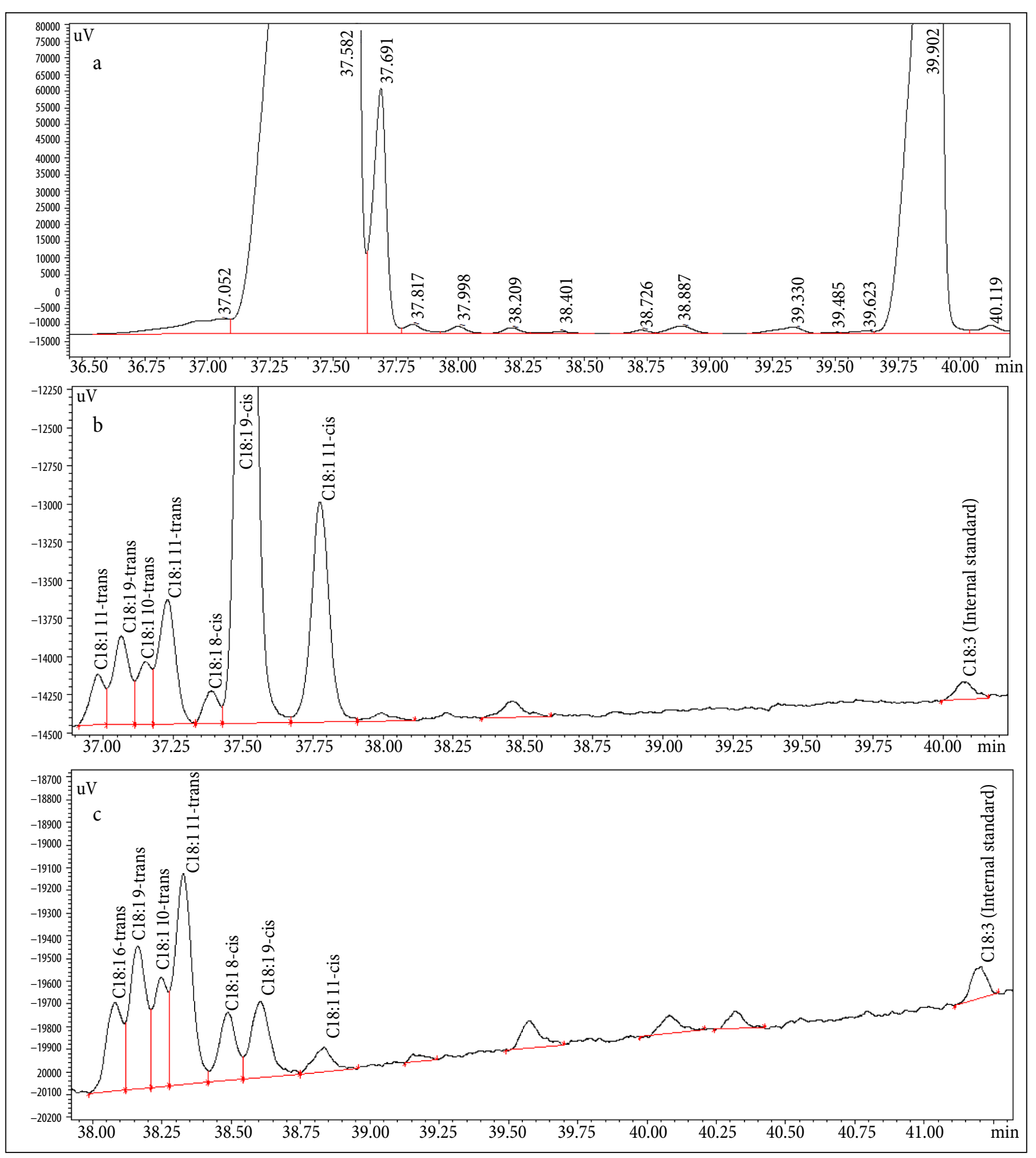

Fig. 3. The chromatogram of human adipose FAME before fractionation (a), after fractionation with a home-made $\mathrm{Ag}^{+}-\mathrm{SPE}$ column (b), after fractionation with a commercial SCX Ag+-SPE column (c)

from trans fractions and their peaks do not interfere with the peaks of trans isomers. The efficiency of the fractionation with the both SPE columns is quite similar with a slightly bigger quantity of cis isomers in the trans fraction for the homemade column.

For the quantitative evaluation of the columns, ten fractionations of adipose tissue with the both columns were performed. The quantification of trans fatty acids was ac- complished by the external standardization method using a calibration curve constructed from elaidic acid methyl ester. The concentrations of trans FAME obtained using the external standardization method for the both columns were similar, relative standard deviations in both cases did not exceed 10\% (Table3).

As it was mentioned above, the fractions collected were evaporated to dryness and diluted to $1 \mathrm{ml}$ with hexane. As 
Ta ble 3. Results of trans FAME determination in human adipose $(n=10)$

\begin{tabular}{|c|c|c|c|c|c|c|c|c|}
\hline \multirow{3}{*}{ Isomer } & \multicolumn{4}{|c|}{ Home-made $\mathrm{Ag}^{+}-\mathrm{SPE}$} & \multicolumn{4}{|c|}{ Commercial SCX Ag ${ }^{+}-S P E$} \\
\hline & \multicolumn{2}{|c|}{ External standardization } & \multicolumn{2}{|c|}{ Internal standardization } & \multicolumn{2}{|c|}{ External standardization } & \multicolumn{2}{|c|}{ Internal standardization } \\
\hline & Amount, \% & sr, $\%$ & Amount, \% & sr, $\%$ & Amount, \% & sr, $\%$ & Amount, \% & sr, $\%$ \\
\hline C18:1-6tr & 0.124 & 9.3 & 0.123 & 13.0 & 0.115 & 10.0 & 0.108 & 9.8 \\
\hline C18:1-9tr & 0.192 & 4.5 & 0.199 & 6.5 & 0.190 & 6.6 & 0.187 & 7.0 \\
\hline C18:1-10tr & 0.119 & 6.0 & 0.116 & 7.4 & 0.116 & 9.0 & 0.109 & 9.0 \\
\hline C18:1-11tr & 0.255 & 9.6 & 0.268 & 6.7 & 0.277 & 6.1 & 0.281 & 6.7 \\
\hline
\end{tabular}

only $1 \mu \mathrm{l}$ of the sample is required for the injection to $\mathrm{GC}$, it should have sense to decrease the final sample volume and thus increase the concentration of the analytes. However, the smaller the dilution volume is, the bigger variation in the volumetric recovery and the bigger uncertainty of the results are obtained.

In order to eliminate some possible loss of analytes during evaporation, volumetric recovery variation in the dilution step and to enhance method sensitivity, the internal standardization method was applied.

The fractionation step eliminates polyunsaturated fatty acids from the trans fraction. This allows one to use methyl linolenate (C18:3 9, 12, 15-cis) as an internal standard. $50 \mu$ of the internal standard $\left(0.01 \mathrm{mg} \mathrm{ml}^{-1}\right.$ in hexane) was added to the trans fraction. Then the fraction was evaporated to dryness, diluted to $50 \mu \mathrm{l}$ and $1 \mu \mathrm{l}$ of the resulted solution was injected for the GC analysis. Repeatabilities of the results with the both SPE columns were rather similar (Table 3) and comparable with those obtained by external standardization. As the final sample size used was $50 \mu \mathrm{l}$ instead of $1 \mathrm{ml}$ used for the external standardization method, the sensitivity of the method significantly increased. This is essential in the case of trans fatty acid analysis in human adipose tissue as the quantity of them is rather low. Considering the facts mentioned above, the internal standard method should be advantageous with respect to the external standardization.

The results presented above demonstrate that the both SPE columns used demonstrate a similar efficiency and are suitable for FAME fractionation. However, the advantage of the home-made $\mathrm{Ag}^{+}-\mathrm{SPE}$ column is its price. The expenses for its preparation are more than 100 times smaller than the price of a commercial SCX $\mathrm{Ag}^{+}-\mathrm{SPE}$.

\section{CONCLUSIONS}

Preparation and operation conditions of a home-made silica based Ag-SPE column were optimized. The results showed that using dichloromethane and hexane with the content of DCM increasing from 15 to $100 \%$ as an eluent, enabled one to eliminate most of the cis isomers of C18:1 fatty acid methyl esters from the trans chromatographic zone and to determine trace contents of C18:1 trans fatty acid methyl esters in human adipose samples. Statistical characteristics demonstrated that either external standardization or internal standardization methods show similar repeatabilities and can be used for the determination of C18:1 trans fatty acid methyl esters in human adipose. Since the internal standard method does not require a precise volume measurement, samples can be concentrated to a very small volume leading to the increased sensitivity for trans fatty acids determination. The home-made silica based $\mathrm{Ag}^{+}$-SPE column was compared with the commercial SCX based $\mathrm{Ag}^{+}$-SPEcolumn using both quantification methods. The home-made $\mathrm{Ag}^{+}$-SPE column demonstrated as good repeatabilities as the commercial one. Due to a good separation efficiency and a low preparation cost the home-made $\mathrm{Ag}^{+}$-SPE column should be considered advantageous for the fractionation of FAME.

Received 30 October 2017 Accepted 13 November 2017

\section{References}

1. R. J. de Souza, A. Mente, A. Maroleanu, et al., BMJ, 351, h3978 (2015).

2. N. T. Bendsen, R. Christensen, E. M. Bartels, A. Astrup, Eur. J. Clin. Nutr., 65, 773 (2011).

3. A. Aro, I. Salminen, J. K. Huttunen, et al., The Lancet, 345, 273 (1995).

4. A. Ascherio, C. H. Hennekens, J. E. Buring, C. Master, M. J. Stampfer, W. C. Willett, Circulation, 89, 94 (1994).

5. A. Ascherio, M. Katan, P. L. Zock, M. J. Stampfer, W. C. Willett, N. Engl. J. Med., 340, 1994 (1999).

6. A. Ascherio, E. B. Rimm, E. L. Giovannucci, D. Spiegelman, M. Stampfer, W. C. Willett, BMJ, 313, 84 (1996).

7. A. Baylin, E. K. Kabagambe, A. Ascherio, D. Spiegelman, H. Campos, J. Nutr., 133, 1186 (2003).

8. G. A. Bray, J. C. Lovejoy, S. R. Smith, et al., J. Nutr., 132, 2488 (2002)

9. P. M. Clifton, J. B. Keogh, M. Noakes, J. Nutr., 134, 874 (2004).

10. A. M. Lottemberg, M. S. Afonso, M. S. F. Lavrador, R. Markondes Makado, E. R. Nakandakare, J. Nutr. Biochem., 23, 1027 (2012).

11. A. A. Bremer, M. Mietus-Snyder, R. H. Lustig, Pediatrics, 129, 557 (2012) 
12. S. K. Gebauer, T. L. Psota, P. M. Kris-Etherton, Lipids, 42, 787 (2007).

13. J. Gaullier, J. Halse, K. Hoye, et al., J. Nutr., 135, 778 (2005).

14. J. W. Bortolotto, C. Reis, A. Ferreira, et al., Obes. Surg., 15, 1265 (2005).

15. S. Momchilova, B. Nikolova-Damyanova, J. Sep. Sci., 26, 261 (2003).

16. M. Dolowy, A. Pyka, J. Chem., 2015, ID 120830 (2015).

17. H. Goto, N. Shionoya, M. Sugie, et al., J. Oleo Sci., 61, 49 (2012).

18. B. Nikolova-Damyanova, J. Chromatogr. A, 1216, 1815 (2009).

19. Supelco Technical Report. Discovery Ag-Ion SPE for FAME Fractionation and Cis/Trans Separation [https://www.sigmaaldrich.com/content/dam/sigma-aldrich/docs/Supelco/ General_Information/t406062.pdf].

20. V. Poškus, V. Vičkačkaitè, G. Brimas, Chemija, 27(3), 179 (2016).
Vilius Poškus, Vida Vičkačkaitė, Julita Dargytė, Gintautas Brimas SAVADARBE் SIDABRO JONŲ KIETAFAZĖS EKSTRAKCIJOS SISTEMA TRANSRIEBALŲ RŪGŠČIŲ ANALIZEI: PALYGINIMAS SU KOMERCINE DISCOVERY Ag-Ion KIETAFAZE EKSTRAKCIJA

Santrauka

Pasiūlyta ir ištirta savadarbė sidabro jonų kietafazès ekstrakcijos sistema naudojant sidabro jonais padengtą silikagelio sorbantą. Sistema skirta išskirti transriebalų rūgščių esterius iš žmogaus riebalinio audinio mėginio. Transriebalų rūgščių esterių frakcija analizuojama dujų chromatografijos metodu. Palygintos savadarbės sidabro jonų kietafazès ekstrakcijos ir komercinès Discovery Ag-Ion SPE sistemos analizinès charakteristikos. Parodyta, kad abi sistemos gali būti naudojamos riebalų rūgščių esteriams frakcionuoti. 
